\title{
Uwagi językoznawcy o kompetencjach odpornościowych (na podstawie profesji nauczyciela akademickiego)
}

\author{
A linguist's remarks on the resilience competencies \\ (on the basis of the proffesion of an academic teacher)
}

\begin{abstract}
The aim of the article is to attempt to situate the term "resilience competence," which is not known to modern lexicographers (and thus troublesome), in the discourse about the competences of a model teacher: the academic teacher of the future. Resilience competences allow people to find themselves in the new, changing social space. In a situation of pandemic, the development of competences is indisputable, regardless of profession. In the profession of a modern, also academic teacher, strengthening resilience seems to be a necessity. Resilience competencies support remote education processes. They undoubtedly facilitate meeting the demands of education in a pandemic.
\end{abstract}

Keywords: education, teacher competencies, resilience, self-promotion, didactics, future education, personal brand

W prezentowanym tekście podejmuję próbę umiejscowienia nienotowanego przez współczesnych leksykografów pojęcia „kompetencje odpornościowe” (ang. resilience 'sprężystość, elastyczność') w dyskursie dotyczącym kompetencji modelowego nauczyciela, w szczególności nauczyciela akademickiego przyszłości. W sytuacji zagrożenia pandemicznego konieczność rozwijania kompetencji odpornościowych, niezależnie od profesji, nie podlega dyskusji. W swoich rozważaniach skupiam się na kompetencjach nauczyciela akademickiego, gdyż to środowisko znam najlepiej - jestem czynnym zawodowo pracownikiem badawczo-dydaktycznym. 


\section{Terminy „nauczyciel” i „,nauczyciel akademicki” a zawodowe kompetencje odpornościowe}

Mam świadomość, że terminy „nauczyciel akademicki” i „nauczyciel” (zatrudniony w systemie oświaty) nie są tożsame. Należy wyraźnie podkreślić, że nauczyciele akademiccy uprawiają odrębną ,profesję, regulowaną w innych przepisach prawnych oraz podlegającą odmiennym wymogom formalnym niż nauczyciele niższych szczebli nauczania"1. Nauczyciel akademicki to, w skrócie, „osoba zatrudniona w szkole wyższej na stanowisku dydaktycznym, badawczo-dydaktycznym lub badawczym, wykształcona w określonej dziedzinie naukowej"2. Pragnę jednak zauważyć, że rudymentarnym składnikiem wyrażenia „nauczyciel akademicki” jest słowo „nauczyciel”. W klasycznych opracowaniach z zakresu pedagogiki i psychologii wyraz ,nauczyciel" jest stosowany w odniesieniu do osoby realizującej proces edukacyjny (Wincenty Okoń, Hanna Hamer, Joanna Keil ${ }^{3}$ ) oraz prowadzącej badania naukowe (Agnieszka Dziedziczak-Foltyn, Jerzy Brzeziński $\left.{ }^{4}\right)$. W tradycyjnej nomenklaturze wyraz „nauczyciel" używany jest jako synonim dydaktyka, szkoleniowca, badacza ${ }^{5}$. Nie podlega dyskusji fakt, że znaczną część pracy nauczyciela akademickiego, zwłaszcza pracownika dydaktycznego i dydaktyczno-badawczego, stanowi dydaktyka. $Z$ tego też powodu podstawowymi warunkami, jakie powinien spełnić kandydat na przyszłego wykładowcę akademickiego, czyli osoba

${ }^{1}$ Zob. więcej: M. Wiśniewska: Tożsamość nauczyciela akademickiego. „Forum Dydaktyczne” 2011, nr 7-8, s. 66 -69. Pobrano z: https://repozytorium.ukw.edu.pl/bitstream/handle/item/1781/ Malgorzata-Wisniewska-Tozsamosc-nauczyciela-akademickiego.pdf?sequence $=1 \&$ isAllowed=y [6.09.2021].

${ }^{2}$ Prawo o szkolnictwie wyższym i nauce. Dział 2: Szkolnictwo wyższe. Rozdział 5: Pracownicy uczelni. https://sip.lex.pl/akty-prawne/dzu-dziennik-ustaw/prawo-o-szkolnictwie-wyzszym-i -nauce-18750400/dz-2-roz-5 [dostęp: 25.02.2021].

3 Por. W. Okoń: Nowy stownik pedagogiczny. „Żak”, Warszawa 1998, s. 255-256; H. Hamer: Klucz do efektywności nauczania. Poradnik dla nauczycieli. Veda, Warszawa 1994, s. 7; J. Keil: , Szukaj własnej drogi”: nauczyciel wychowawca w myśli pedagogicznej Janusza Korczaka. W: Myśl pedeutologiczna i dziatanie nauczyciela. Red. A.A. Kotusiewicz. T. 2. Trans Humana, Białystok 2000, s. 45.

${ }^{4}$ Por. A. Dziedziczak-Foltyn: Nauczyciele akademiccy jako prekursorzy i moderatorzy spoteczeństwa wiedzy. „Nauka i Szkolnictwo Wyższe” 2006, nr 2 (28), s. 68. Pobrano z: https://pressto. amu.edu.pl/index.php/nsw/article/view/4789 [6.09.2021]; J. Brzeziński: Rozważania o uniwersytecie. W: Edukacja wobec zmiany społecznej. Red. J. Brzeziński, L. Witkowski. Wydawnictwo Edytor, Poznań-Toruń 1994, s. 31-32.

${ }^{5}$ Por. S. Wołoszyn: [hasło:] Nauczyciel. W: Encyklopedia pedagogiczna. Red. W. Pomykało. Fundacja „Innowacja”, Warszawa 1993, s. 444-445. 
ubiegająca się o stanowisko asystenta ${ }^{6}$, są wykształcenie wyższe (co najmniej magisterskie) oraz przygotowanie pedagogiczne, które można uzyskać na kwalifikacyjnych studiach podyplomowych. Zaliczenie bloku zajęć metodycznych (realizowanych w ciągu trzech semestrów) jest warunkiem koniecznym pełnienia funkcji nauczyciela akademickiego7. Nauczyciel akademicki, poza tym, że pełni społeczną rolę pedagoga, jest również — przywołując słowa Floriana Znanieckiego - naukowcem oraz mistrzem ${ }^{8}$. Rozwija karierę naukową, uzyskując kolejne stopnie naukowe i piastujące różne stanowiska. Wraz z długością stażu i zdobytymi kwalifikacjami może uzyskać tytuł profesora.

W kanonicznych podręcznikach do kształcenia przyszłych nauczycieli ${ }^{9}$, w tym nauczycieli akademickich, akcentuje się misyjność zawodu (Zofia Żukowska $^{10}$ ) oraz określa cechy, jakimi wzorcowy nauczyciel powinien się kierować w pracy i życiu (Krzysztof Konarzewski, Stanisław Jedynak, Jerzy Kojkoł, Krzysztof Andrzej Wojcieszek ${ }^{11}$ ). Obecnie pedagodzy i psycholodzy dodatkowo zwracają uwagę, że cechą konstytutywną nauczyciela przyszłości powinna być indywidualność/kreatywność ${ }^{2}$. Kompetencje zawodowe nauczycieli (w tym wykładowców akademickich) można — za Stanisławem Dylakiem — podzielić na trzy grupy:

${ }^{6}$ Ścieżka kariery akademickiej rozpoczyna się zazwyczaj od (zajmowanego na podstawie wygrania konkursu ogłaszanego przez władze uczelni) stanowiska asystenta (potocznie określanego „pomocniczym pracownikiem nauki”). Zob. P. Kaniok: Kto może zostać nauczycielem akademickim. Wyższa Szkoła Kształcenia Zawodowego. 20.04.2021. https://studia-pedagogiczne.pl/ aktualnosci/kto-moze-zostac-nauczycielem-akademickim/ [dostęp: 25.05.2021].

${ }^{7}$ Ibidem.

${ }^{8}$ F. Znaniecki: Społeczne role uczonych. Wybór, wstęp, przekł. tekstów ang. i red. nauk. J. Szacki. Państwowe Wydawnictwo Naukowe, Warszawa 1984.

${ }^{9}$ Nauczyciel akademicki, tak jak każdy nauczyciel zatrudniony w systemie oświaty, jest zobligowany poznać opracowania te już na początku swej drogi zawodowej w toku zajęć specjalizacyjnych.

${ }_{10}$ Pisze o tym Zofia Żukowska - podaję za: K. Głowania: Modelowa sylwetka wspótczesnego nauczyciela akademickiego. W: Edukacja w zglobalizowanym świecie. Red. V. Tanaś, W. Welskop. Wydawnictwo Naukowe Wyższej Szkoły Biznesu i Nauk o Zdrowiu, Łódź 2016, s. 410 .

${ }^{11}$ K. Konarzewski: Nauczyciel. W: Sztuka nauczania. Szkoła. Podręcznik dla studentów kierunków nauczycielskich. [T.] 2. Red. K. Konarzewski. [Wyd. 2]. Wydawnictwo Naukowe PWN, Warszawa 1993, s. 148-149; Encyklopedia filozofii wychowania. Red. S. Jedynak, J. Kojkoł. Oficyna Wydawnicza Branta, Bydgoszcz 2009, s. 78—79; K.A. Wojcieszek — w: Tylko 20\% uczniów i studentów lubi się uczyć. Wirtualna Polska. Wiadomości. 26.03.2004. http://wiadomosci.wp.pl/ kat,1342,title,tylko-20-uczniow-i-studentow-lubi-sie-uczyc-wid,5084131, wiadomoschtml?ticaid =1174fd [dostęp: 6.09.2021].

12 S. Korczyński: Obraz nauczyciela w polskiej myśli pedeutologicznej. WSP, Opole 1992, s. 55; B. Gołek: Kompetencje współczesnego nauczyciela (wybrane obszary). „Rocznik Komisji Nauk Pedagogicznych PAN" 2014, T. 67, s. 92, 95. 
- kompetencje bazowe, ułatwiające proces komunikacji;

- kompetencje konieczne, czyli te, „bez których osoby uprawiające zawód nauczyciela nie mogłyby skutecznie wypełniać [...] zadań edukacyjnych [...]: interpretacyjne, autokreacyjne oraz realizacyjne"13;

- kompetencje pożądane, to znaczy takie, które nie są wprawdzie niezbędne w zawodzie, ale mogą być pomocne, czyli na przykład zainteresowania i umiejętności związane ze sportem, sztuką czy z życiem społecznym.

Prezentowane w niniejszym tekście spostrzeżenia na temat zawodowych kompetencji odpornościowych nauczyciela mają charakter przyczynkarski, co wyraźnie zostało zapowiedziane w tytule. Dlatego też nie opisuję szeroko kompetencji odpornościowych, a jedynie przywołuję elementy składowe/,,budujące" przywoływany termin i wystarczające do tego, by go oddzielić od innych do niego podobnych. Szczegółowa analiza poszczególnych komponentów odróżniających „kompetencje odpornościowe” od innych z bogatego repertuaru kompetencji ${ }^{14}$ wykracza poza zadania wyznaczone w niniejszym tekście ${ }^{15}$.

\section{Tradycyjny model nauczyciela (także akademickiego) wobec pandemii COVID-19}

Według klasycznego modelu nauczania nauczyciel (także nauczyciel akademicki) ma być przede wszystkim specjalistą w swojej dziedzinie, wychowawcą budzącym i wspierającym autoedukacyjne potrzeby swoich uczniów/ studentów, inspiratorem/animatorem, organizatorem i realizatorem działań

${ }^{13}$ Według Stanisława Dylaka „nauczyciel, który działa w różny sposób, ale zawsze adekwatnie do określonych sytuacji, jest nauczycielem kompetentnym interpretacyjnie w zakresie trzech wymienionych komponentów. Dzięki kompetencjom autokreacyjnym nauczyciel jest twórcą własnej wiedzy pedagogicznej. Niewątpliwie wśród kompetencji koniecznych najbogatszy obszar stanowią umiejętności realizacyjne, dzięki którym nauczyciel urzeczywistnia listę zadań edukacyjnych. [...] mogą być one rozpatrywane w trzech wymiarach: obiektu, na który jest czynność skierowana, poziomu zorganizowania oraz ogólnego schematu działania”. S. Dylak: Wizualizacja w kształceniu nauczycieli. Wydawnictwo Naukowe UAM, Poznań 1995, s. 38-39.

${ }^{14}$ Lista kompetencji jest otwarta. Specjaliści ustawicznie tworzą różne ich zestawy. Autorzy niektórych sprofilowanych, branżowych opracowań przywołują nawet do trzystu kompetencji. Zob. Ch. Woodruffe: Ośrodki oceny i rozwoju. Narzędzia analizy i doskonalenia kompetencji pracowników. Oficyna Ekonomiczna, Kraków 2003.

15 Drobiazgowa analiza porównawcza wystąpień leksemu „rezyliencja” w słownikach języka polskiego i angielskiego została ukończona, a publikacja wyników badań planowana jest w 2022 roku w anglojęzycznym czasopiśmie o profilu edukacyjnym - A.B. Strawińska, A. Dzięcioł-Pędich: ,Rezyliencja” w polskich i angielskich źródłach leksykograficznych [w przygotowaniu]. 
edukacyjno-kulturowych ${ }^{16}$. Ten zakorzeniony $\mathrm{w}$ tradycji model nauczania, w tym edukacji akademickiej, w Polsce (i nie tylko) został skonfrontowany z nową rzeczywistością. Stanęliśmy przed wielkim wyzwaniem organizacyjnym — koniecznością radykalnej zmiany sposobów kształcenia. Współczesny nauczyciel, także akademicki, musiał w bardzo krótkim czasie dostosować się do nowej sytuacji - do wypełniania nowych zadań. Dzisiejszy/nowoczesny nauczyciel akademicki, nauczyciel akademicki najwyższej próby, „ma być przede wszystkim czynnym badaczem, a dopiero potem dydaktykiem. Student powinien nie tylko słuchać tego, co mówi profesor, a co można i tak przeczytać, ale powinien [...] poznawać wiedzę w procesie jej stawania się"17. Taki nauczyciel, zdaniem Andrzeja Kajetana Wróblewskiego, odpowiada na potrzeby współczesnego rynku pracy ${ }^{18}$. Młode pokolenie studentów „oczekuje nie tyle »nauczania« (wiedza że), co »eksperckiej« porady (wiedza jak)" ${ }^{\prime \prime}$. Wynika to z faktu, iż obecnie głównym źródłem informacji jest Internet. Współczesny student świat bez globalnej sieci komputerowej zna wyłącznie z opowieści. Wirtualna rzeczywistość to jego „,naturalny habitat, do którego dociera nie tylko poprzez komputery, ale również za pośrednictwem tabletów lub/i telefonów komórkowych" ${ }^{20}$. Pedagodzy XXI wieku organizujący proces kształcenia powinni mieć tego świadomość i poszukiwać takich rozwiązań dydaktycznych, które będą przede wszystkim odpowiednio dostosowane do tego, kim jest współczesny uczeń/słuchacz/student/klient ${ }^{21}$. Potrzeba korzystania $\mathrm{z}$ ułatwień, dostępnych dzięki postępowi technicznemu wymaga od nauczyciela akademickiego (jak również od każdego wykształconego człowieka) nieustannej „renowacji wiedzy, uzupełniania i przekształcania opanowanych umiejętności

16 S. Wołoszyn: [hasło:] Nauczyciel..., s. 444-445.

${ }^{17}$ A. Dziedziczak-Foltyn: Nauczyciele akademiccy jako prekursorzy i moderatorzy spoteczeństwa wiedzy..., s. 68.

18 Jak pisze Andrzej Kajetan Wróblewski, absolwenci uniwersytetu przyszłości muszą nauczyć się być ludźmi twórczymi, a najlepiej się nimi stać poprzez bezpośrednie doświadczanie procesu tworzenia; powinni też — pośrednio za sprawą wykładowcy akademickiego — zdobyć wykształcenie, które zapewni im możliwość stałego przystosowywania się do nowych warunków, będących następstwem rozwoju wiedzy i technologii. Zob. A.K. Wróblewski: Wizja uniwersytetu przyszłości. „Nauka” 2010, nr 2, s. 12.

19 A. Kuś: Ludzie Uniwersytetu w dobie globalizacji. W: V. Tanaś, W. Welskop: Edukacja w zglobalizowanym świecie..., s. 156.

${ }^{20}$ B. Sajduk: Nowoczesna dydaktyka akademicka. Kto kogo uczy? Wyższa Szkoła Europejska im. ks. Józefa Tischnera, [s.1.] 2015, s. 13. https://doi.org/10.13140/2.1.4043.2969.

${ }^{21} \mathrm{~W}$ kontekście personal brandingu, to znaczy w odniesieniu do procesu budowania marki osobistej i traktowania siebie w kategoriach produktu, współczesny nauczyciel jest tym, który „sprzedaje” wiedzę, a nabywcą tej wiedzy jest student-klient. Por. A.B. Strawińska: Historia i definicja terminu ,personal branding”. Zarys problematyki. W: Socjolekt - idiolekt - idiostyl. Historia i wspótczesność. Red. U. Sokólska. Uniwersytet. Wydział Filologiczny-Wydawnictwo Prymat, Białystok 2017, s. 365-387. 
i sprawności, myślenia giętkiego, krytycznego i heurystycznego, osobowości nieustannie angażującej się poznawczo i emocjonalnie"22.

Harmonijna kompozycja wiedzy, sprawności, rozumienia oraz pragnienia między innymi szeroko pojętych zmian, według Marii Czerepaniak-Walczak, składa się „na »magiczne« słowo »kompetencja«"23. Kompetencję, według Wacława Strykowskiego, „można wyrazić myślą: pragnę to zrobić dobrze" 24 .

\section{Słowo „kompetencja” w źródłach leksykograficznych a kompetencje zawodowe nauczyciela (również akademickiego)}

Wyraz „,kompetencja” jest zapożyczeniem z języka łacińskiego (łac. competentia 'zgodność, odpowiedniość') ${ }^{25}$ i oznacza 'zdolność wyrokowania o czym; biegłość; dokładne wtajemniczenie się w sprawę'26, 'fachowość, znanie się na rzeczy'27, 'zakres czyjejś wiedzy, umiejętności lub odpowiedzialności' ${ }^{28}$. Jak podają Andrzej Markowski i Ryszard Pawelec, omawiany leksem we współczesnej polszczyźnie najczęściej jest stosowany w liczbie mnogiej: „kompeten-

${ }^{22}$ Według Stefana Wołoszyna wyraża to idea edukacji permanentnej. S. Wołoszyn: [hasło:] Nauczyciel..., s. 444.

${ }^{23}$ M. Czerepaniak-Walczak: Refleksja krytyczna i jej miejsce $w$ dyskusji nad reformowaniem oświaty (próba zastosowania). „Rocznik Pedagogiczny” 1997, nr 20, s. 32; Eadem: [hasło:] Kompetencja. W: Jakość kształcenia w szkolnictwie wyższym. Stownik tematyczny. Red. M. Wójcicka. Centrum Badań Polityki Naukowej i Szkolnictwa Wyższego, Uniwersytet Warszawski, Warszawa 2001, s. 69.

${ }^{24}$ W. Strykowski: Kompetencje współczesnego nauczyciela. „Neodidagmata” 2005, nr 27/28, s. 17. Pobrano z: https://repozytorium.amu.edu.pl/bitstream/10593/3096/1/strykowski.pdf [17.05.2016].

${ }^{25}$ Por. Uniwersalny stownik języka polskiego. Red. S. Dubisz. T. 1. Wydawnictwo Naukowe PWN, Warszawa 2003, s. 390: kompetencja <niem. Kompetenz, fr. compétence>.

${ }^{26}$ Stownik języka polskiego. Red. J. Karłowicz, A. Kryński, W. Niedźwiedzki. T. 2. [Nakładem prenumeratorów i kasy im. Mianowskiego], Warszawa 1902, s. 426. https://ebuw.uw.edu.pl/ publication/254 [dostęp: 24.04.2021].

27 Etymologia za: Słownikiem języka polskiego. Red. M. Orgelbrand. [Nakładem autora], Wilno 1861. Zob. A. Markowski, R. Pawelec: Stownik wyrazów obcych i trudnych. Wilga, Warszawa 2001, s. 393.

${ }^{28}$ Przytaczam znaczenia za: Stownik języka polskiego. Red. M. Szymczak. T. 1. Wyd. 7. zm. i popr. Wydawnictwo Naukowe PWN, Warszawa 1992, s. 997; Słownik współczesnego języka polskiego. Red. B. Dunaj. T. 1. Wyd. 2. Warszawa 2000, s. 397. 
cje” w znaczeniu 'zakres (zwykle formalny) czyichś uprawnień, pełnomocnictwo do jakiegoś działania'29.

Astrid Męczkowska w badaniach pedagogicznych wyróżnia dwa ujęcia kompetencji. Pierwsze traktuje kompetencję jako adaptacyjny potencjał podmiotu i zakłada, że

każdy rodzaj zachowania człowieka jest zachowaniem sprawczym: jest ono zawsze instrumentem, służącym osiąganiu przez podmiot kontroli nad zewnętrznym — społecznym bądź przyrodniczym — otoczeniem i jako takie podlega modelowaniu [...]. Drugie ujęcie traktuje kompetencje jako transgresyjny potencjał podmiotu. Jest to przekonanie, że kompetencja jest rodzajem głębokiej struktury poznawczej, integrującej funkcjonujące w jej ramach elementy oraz równoważącej relacje człowieka ze światem ${ }^{30}$.

Fundament, bazę „kompetencji” — według Małgorzaty Kossowskiej oraz Iwony Sołtysińskiej — stanowią wiedza deklaratywna (wiem „co”), umiejętności (wiedza proceduralna — wiem ,jak” i potrafię) oraz postawy (chcę i jestem gotów wykorzystać swą wiedzę) $)^{31}$.

W klasycznych opracowaniach uwzględnia się rolę nauczyciela w generowaniu określonych zachowań i przywołuje się kompetencje:

- wyjściowe (adaptacyjne);

- dojrzałe (rekonstrukcyjne);

- do zmiany (transgresyjne); oraz

- rdzeniowe, esencjonalne, tak zwane emancypacyjne ${ }^{32}$.

${ }^{29}$ A. Markowski, R. Pawelec: Stownik wyrazów obcych i trudnych ..., s. 393.

${ }^{30}$ A. Męczkowska: [hasło:] Kompetencja. W: Encyklopedia pedagogiczna XXI wieku. Red. T. Pilch. T. 2. Wydawnictwo Akademickie „Żak”, Warszawa 2009, s. 693-695. Termin „kompetencja" - przywołuję tutaj Jacques’a Delorsa — jest tworem złożonym i oznacza zespół skonkretyzowanych właściwości/przymiotów; dokładniej jest to „połączenie wiedzy i umiejętności działania z osobistym zaangażowaniem i umiejętnością bycia”. Edukacja - jest w niej ukryty skarb. Raport dla UNESCO Międzynarodowej Komisji ds. Edukacji dla XXI wieku. Pod przewodnictwem Jacques'a Delorsa. [Tłum. W. Rabczuk]. Stowarzyszenie Oświatowców PolskichWydawnictwa UNESCO, Warszawa 1998, s. 90. Zob. także S. Dylak: Wizualizacja w ksztatceniu nauczycieli..., s. 37.

${ }^{31}$ Podaję za: B. Kozak-Łatkowska: Koncepcja kompetencji w zarządzaniu zasobami ludzkimi w kontekście uczenia się przez całe życie. Szkolenia.com. https://www.szkolenia.com/news/806/ koncepcja-kompetencji-w-zarzadzaniu-zasobami-ludzkimi-w-kontekscie-uczenia-sie-przez-calezycie [dostęp: 17.05.2016].

32 Por. M. Czerepaniak-Walczak: Kompetencja: słowo kluczowe czy ,wytrych” w edukacji? „Neodidagmata” 1999, nr 24, s. 65-65. Pobrano z: https://repozytorium.amu.edu.pl:8080/bitstream/10593/6514/1/04_Maria_Czerepaniak_Walczak_KOMPETENCJA_S\%C5\%810WO_KLUCZOWE_53-66.pdf [6.09.2021]. 
Po wpisaniu hasła „kompetencje nauczyciela” do wyszukiwarki MoncoPL ${ }^{33}$ w wynikach pojawia się dwadzieścia sześć konkordancji ${ }^{34}$. MoncoPL jest

narzędziem, które opierając się na składni zapytań, właściwej wyszukiwarce PELCRA, obsługującej Narodowy Korpus Języka Polskiego ${ }^{35}$, pozwala przeglądać zasoby internetowe wyselekcjonowane i ograniczone do tysiąca źródeł (pod względem stylistycznym są to w dużej mierze teksty publicystyczne). Daje tym samym szansę odnalezienia przykładów użycia słownictwa najnowszego, co można uznać za swoiste uzupełnienie NKJP ${ }^{36}$.

Źródła, z których pochodzą konteksty występowania jednostki „kompetencje nauczyciela", to: gostynin24.pl, chodziez.naszemiasto.pl, ngo.pl, interia.pl, trojmiasto.pl, forsal.pl, news.google.com, ostrowmaz24.pl, chojnice24.pl, edukacja-nauczyciel.blog.onet.pl, wiara.pl, niedziela.pl, katolik.pl, portalsamorzadowy.pl, interia.pl, niezalezna.pl, naszraciborz.pl ${ }^{37}$. Jak wynika z danych korpusowych, największa częstotliwość występowania jednostki „kompetencje nauczyciela" notowana była jesienią 2017 roku. Pierwsze wystąpienie hasła „kompetencje nauczyciela” odnotowano w wyszukiwarce MoncoPL 17 stycznia 2013 roku; ostatnie notowanie pochodzi z 29 października 2020 roku. Wyszukiwarka wskazuje osiem tekstów-komunikatów zawierających wyrażenie „kompetencje nauczyciela”. Przywoływany termin występuje w nich mię-

${ }^{33}$ MoncoPL. http://monco.frazeo.pl/ [dostęp: 11.01.2021]. Korpus ,pomaga znaleźć przykłady użycia wyrazów, fraz oraz wzorców leksykalno-gramatycznych w autentycznych próbkach współczesnej polszczyzny". Indeks wyszukiwarki jest systematycznie uaktualniany. Obecnie zawiera ponad pięć miliardów segmentów słów. Ogląd danych językowych możliwy jest w ramach czterech modułów: konkordancje, podsumowanie, fasety (typy tekstów), pliki.

${ }^{34} \mathrm{~W}$ zestawie trzydziestu siedmiu wystąpień wyrażenia „kompetencje nauczyciela” powtarzają się takie komponenty, jak: kompetencje pedagogiczne, mediacyjne, informatyczne, kompetencje e-nauczyciela. http://monco.frazeo.pl $/$ search?q $=$ kompetencje $\& \mathrm{o}=0$ on $\& \mathrm{sf}=0 \& \mathrm{o}=\mathrm{on} \& \mathrm{~d}=1 \& \mathrm{dq}=$ $\& d \operatorname{cor}=\mathrm{id}+\mathrm{asc} \& \mathrm{cs}=1 \& \mathrm{cht}=\mathrm{on} \& \mathrm{f}=\& \mathrm{t}=\& \mathrm{p}=1 \& \mathrm{sd}=2021-01-12+02 \% 3 \mathrm{~A} 37 \% 3 \mathrm{~A} 11 \& \mathrm{l}=20 \#$ results [dostęp: 11.01.2021]. Zob. też: https:/dobryslownik.pl/slowo/konkordancja/86695/ [dostęp: 11.01.2021].

${ }^{35}$ Narodowy Korpus Języka Polskiego (NKJP) jest wspólną inicjatywą Instytutu Podstaw Informatyki PAN (koordynator), Instytutu Języka Polskiego PAN, Wydawnictwa Naukowego PWN oraz Zakładu Językoznawstwa Komputerowego i Korpusowego Uniwersytetu Łódzkiego. NKJP to nie tylko zbiór tekstów ilustrujących typowe użycia słów i konstrukcji językowych, lecz także źródło innych informacji o znaczeniu i funkcji odnotowanych jednostek. Na liście źródeł Korpusu znajduje się — poza klasyką literatury polskiej — również prasa codzienna i specjalistyczna, nagrania rozmów, teksty ulotne i internetowe. NKJP. Narodowy Korpus Języka Polskiego. http:// nkjp.pl/ [dostęp: 30.01.2020].

${ }^{36}$ B. Duda, K. Lisczyk: Narzędzia cyfrowe w polonistycznej dydaktyce akademickiej - zastosowania, możliwości, perspektywy. „Forum Lingwistyczne” 2018, nr 5, s. 148. Pobrano z: https:// www.journals.us.edu.pl/index.php/FL/article/view/7432 [11.01.2021].

37 Szczegółowe dane znaleźć można na stronie http://monco.frazeo.pl/ [dostęp: 14.01.2021]. 
dzy innymi jako składnik tytułu artykułu prasowego czy literatury fachowej przytaczanej w tekście oraz element śródtytułu:

Kompetencje nauczyciela - jak je rozwijać? (naszraciborz.pl z 29.10.2020).

D. Krzywoń: Kompetencje nauczyciela $w$ zreformowanej szkole. W: M.T. Michalewska. Red. Kompetencje nauczycieli w zreformowanej szkole. Katowice 2003 (katolik.pl z 6.11.2017).

Kompetencje nauczyciela a jakość szkoły (portalsamorzadowy.pl z 20.11.2017).

Niepokoja się też o niedoinwestowane szkoty, o konieczność tworzenia dużych klas, pytaja o kompetencje nauczycieli i program nauczania, który rodzice z ratujmaluchy.pl nazywaja tresura (wiara.pl z 2.09.2014).

$\mathrm{Z}$ danych zebranych w MoncoPL wynika, że termin „kompetencje nauczyciela" traktowany jest przez użytkowników polszczyzny jako synonim umiejętności, dyspozycji, uwarunkowań psychicznych oraz kwalifikacji. Oto przykładowe konteksty:

Kompetencje nauczyciela musza być w tej chwili naprawdę odpowiadajace rewolucji 4.0. (portalsamorzadowy.pl z 13.10.2017).

Praca pedagoga-wychowawcy to nie tylko kompetencje realizacyjne (wykonawcze), ale również kompetencje interpretacyjne (katolik.pl z 6.11.2017).

Za najważniejszy element procesu dydaktycznego uważała kompetencje nauczyciela, w tym jego charyzmę, empatię i moralność (interia.pl z 23.05.2012).

Podstawowa sprawa to świadectwo oraz kompetencje nauczyciela $i$ katechety, a także madry, przemyślany program wychowawczy $i$ dydaktyczny (niedziela.pl z 2.09.2017).

Jest bardzo istotne, aby rozwijać kompetencje nauczycieli języków, którzy będa zdolni nie tylko do wprowadzania strategii nauczania $w$ klasie, ale także do inspirowania i motywowania uczniów (onet.pl z 12.04.2015).

Współczesna rzeczywistość wymusza na nauczycielu (nie tylko akademickim) posiadanie/wypracowanie całego kompleksu kompetencji, tj.: merytorycznych (rzeczowych), psychologiczno-pedagogicznych, diagnostycznych (związanych z poznawaniem środowiska i uczniów/studentów), dydaktyczno-metodycznych, komunikacyjnych, medialnych i technicznych, związanych 
z kontrolą osiągnięć uczniów/studentów oraz jakościowym pomiarem pracy szkoły/uczelni, dotyczących projektowania oraz oceny programów i podręczników szkolnych/akademickich oraz autoedukacyjnych, związanych z rozwojem zawodowym ${ }^{38}$. Z badań przeprowadzonych przez CBOS jasno wynika, że status nauczyciela (także akademickiego) jest z roku na rok coraz niższy ${ }^{39}$. Specjaliści od marketingu i zarządzania przyczyn tego stanu upatrują między innymi w niedocenianiu przez tę grupę zawodową nowoczesnych technik autopromocyjnych. Zaleca się, by nauczyciele każdego szczebla wykorzystywali w swojej pracy osiągnięcia tak zwanego marketingu osobistego, którego podstawowym zadaniem jest „wzbudzanie zainteresowania, ekscytacji i podziwu [...] poprzez stosowanie chwytliwych technik komunikacyjnych, wykorzystywanie nowoczesnych technologii, a także czerpanie korzyści z pozytywnego »szumu« wokół siebie" podczas nauczania na odległość, naukowiec, podobnie jak sprzedawca wprowadzający na rynek nowy produkt, swoją wiedzę i siebie musi potrafić skutecznie wypromować. Zgodnie z wytycznymi stworzonymi przez ekspertów od kreowania wizerunku podstawowym celem autopromocji jest dążenie do sprawienia wrażenia osoby kompetentnej poprzez deklaracje kompetencji, inscenizacje pokazów kompetencji oraz niezbędne do tego celu rekwizyty ${ }^{41}$. Celem autopromocji wykładowców akademickich jest wykazanie zdolności do osiągania sukcesów. W definiowaniu strategii autopromocji nauczycieli akademickich istotne są przede wszystkim ich kompetencje autokreacyjne oraz komunikacyjne. W inscenizacji pokazów kompetencji ważne jest - najogólniej rzecz ujmując — to, w jaki sposób nauczyciel akademicki przekazuje informacje, a więc odpowiednia modulacja głosu oraz akcentowanie. Z kolei rekwizyty kompetencji w kontekście pracy nauczyciela akademickiego należy rozumieć jako część akademicko-teatralnego świata, w którym rekwizyt w komunikowaniu ze studentami ma szczególne znaczenie — jest źródłem symboli, wzorców oraz emocji ${ }^{42}$. Praca nauczyciela akademickiego w dobie pandemii powinna być skorelowana z nowym typem odbiorcy informacji, tak zwanym homo videns, którego percepcja nakierowana jest przede wszystkim na obraz.

${ }^{38}$ Podaję za: W. Strykowski: Kompetencje współczesnego nauczyciela..., s. 18.

39 Więcej: A.B. Strawińska: Autopromocja w edukacji akademickiej. W: Edukacja polonistyczna. Metamorfozy kontekstów i metod. Red. M. Karwatowska, L. Tymiakin. Wydawnictwo Uniwersytetu Marii Curie-Skłodowskiej, Lublin 2017, s. 144-145.

${ }^{40}$ P. Klaus: Daj się poznać od najlepszej strony. Krótki kurs autopromocji i lansu. [Tłum. M. Czub]. Wydawnictwo Helion, Gliwice 2010, s. 1.

${ }^{41}$ Więcej o sztuce autoprezentacji między innymi w: M. Leary: Wywieranie wrażenia na innych. O sztuce autoprezentacji. Tłum. A. Kacmajor, M. Kacmajor. Wyd. 2 w jęz. pol. Gdańskie Wydawnictwo Psychologiczne, Gdańsk 2007.

${ }^{42}$ Szczegółowego opisu technik autopromocyjnych nauczyciela akademickiego dokonałam w: A.B. Strawińska: Autopromocja w edukacji akademickiej..., s. 149-162. 
W sytuacji bezpośredniego zagrożenia życia i zdrowia nie tyle najbardziej pożądaną, ile konieczną - według znawców zagadnienia - właściwością/ cechą człowieka jest niepodatność (wytrzymałość) na czynniki zewnętrzne; umiejętność ,dostosowywania [...] do zmieniających się warunków, [...] plastyczność umysłu [...] i odporność na działanie szkodliwych czynników"ł3, głównie szeroko rozumianego stresu ${ }^{44}$. W internetowym Słowniku języka polskiego $P W N$ „człowieka odpornego" definiuje się jako "niewrażliwego na wpływy fizyczne lub moralne ${ }^{45}$.

\section{„Kompetencje odpornościowe” jako tak zwane kompetencje zawodowe}

„Kompetencje odpornościowe” człowieka są częścią większej struktury, którą psychologowie nazywają „,siłą i odpornością psychiczną”. „Siła i odporność psychiczna" wsparta jest na takich filarach, jak:

wyzwanie 'nowe i trudne zadanie lub sytuacja, które wymagają wysiłku i uporu, by sobie z nimi poradzić (ang. challenge)'; pewność siebie 'wysoki poziom wiary w siebie i wysoka samoocena (ang. confidence)'; zaangażowanie 'wytrwałość w realizowaniu zadań i umiejętność finalizacji działań (ang. commitment)' oraz poczucie wpływu/kontrola 'przekonanie, że mam wpływ i umiejętność zarządzania swoimi emocjami (ang. control) ${ }^{46}$.

Badacze tematu odporności psychicznej są zgodni co do tego, że istnieją tacy ludzie, którzy po prostu rodzą się z wysokim poziomem rezyliencji. Dla większości osób jednak jest to kompetencja, której można, a nawet należy się nauczyć. Ewa Wędrychowska - coach kariery, doradca zawodowy, konsul-

${ }^{43}$ Rezyliencja z ang. resilience 'sprężystość, elastyczność, prężność'. https://pl.wikipedia. org/wiki/Rezyliencja [dostęp: 30.12.2019].

${ }^{44}$ Zob. Co to jest Model Kompetencji Zawodowych (MKZ)? Biuro Karier. Uniwersytet Mikołaja Kopernika w Toruniu. https://www.biurokarier.umk.pl/model-kompetencji-zawodowych1 [dostęp: 12.01.2021]. Odporność człowieka oznacza, że posiada on umiejętność dążenia do celu, potrafi pokonywać przeszkody i niedogodności; sprawnie podnosi się po porażkach; wszystkie cele realizuje konsekwentnie i finalizuje rozpoczęte przedsięwzięcia.

${ }^{45}$ Odporność. Słownik Języka Polskiego PWN. https://sjp.pwn.pl/sjp/odporny;2493503.html [dostęp: 30.12.2019].

${ }_{46}$ M. Henke: Rezylientne przywództwo - czy leci z nami pilot? Małgorzata Henke szkolenia dla biznesu. 2.08.2020. http://malgorzatahenke.pl/2020/08/02/rezylientne-przywodztwo/ [dostęp: 15.09.2020]. 
tant HR - rozwijanie w sobie mocnej rezyliencji przyrównuje do „budowania wokół siebie [...] »warstwy ochronnej«, [...] [która - A.B.S.] nas osłoni przed wstrząsem, upadkiem czy innymi przeszkodami”, i zaleca „podniesienie poziomu rezyliencji własnej” poprzez budowanie poczucia wartości. Podwyższenie poczucia własnej wartości z kolei, zdaniem badaczki, można osiągnąć dzięki dostrzeżeniu własnych talentów, przeświadczeniu o tym, że wyznaczone przez siebie cele uda się pozytywnie sfinalizować, zaangażowaniu w działalność charytatywną, a także poprzez dbanie o zdrowie ${ }^{47}$.

Termin „kompetencje odpornościowe” nie został odnotowany w drukowanych źródłach leksykograficznych i encyklopedycznych. W NKJP również nie znajdziemy hasła „kompetencje odpornościowe” ani haseł „kompetencje nauczyciela” czy „rezyliencja”. Miałam nadzieję, że w sprecyzowaniu kompetencji odpornościowych współtworzących model nowego/nowoczesnego nauczyciela akademickiego pomoże mi jedno z najnowocześniejszych leksykograficznych narzędzi cyfrowych, a mianowicie wyszukiwarka MoncoPL. Niestety i to źródło zawiodło. MoncoPL terminu „kompetencje odpornościowe" nie poświadcza. Tymczasem na podstawie krajowej i zachodniej literatury z zakresu psychologii i pedagogiki da się stworzyć spektrum kompetencji odpornościowych. Z najnowszych badań wynika, że termin „kompetencje odpornościowe" obejmuje takie komponenty, jak: asertywność, odpowiedzialność, integralność, niezależność, odwaga, odporność na stres, „ukierunkowanie na potrzeby cyfrowych tubylców" ${ }^{48}$, upór, wytrwałość oraz konsekwencja ${ }^{49}$. Obfitość słownikowych objaśnień każdej z wymienionych cech składających się na pojęcie „kompetencje odpornościowe” umożliwia stworzenie omówienia/minimonografii tego terminu $\mathrm{z}$ uwzględnieniem szerokiej semantyczno-kulturowej perspektywy. Zadanie to jednak nie jest celem niniejszego opracowania. Tekst niniejszy taktować należy jako przyczynek do dalszych badań o charakterze interdyscyplinarnym.

${ }^{47}$ E. Wędrychowska: Rezyliencja - 5 sposobów na to, jak budować swoja ,,warstwę ochronna”, by radzić sobie w trudnych doświadczeniach zawodowych. Ewa Wędrychowska blog. http:// ewedrychowska-coaching.pl/blog/rezyliencja-5-sposobow-na-to-jak-budowac-swoja-warstweochronna-by-radzic-sobie-w-trudnych-doswiadczeniach-zawodowych/ [dostęp: 12.01.2021].

${ }^{48}$ Termin przywoływany przez Błażeja Sajduka w: Nowoczesna dydaktyka akademicka...

49 Zob. R. Hanson, F. Hanson: Rezyliencja. Jak ukształtować fundament spokoju, siły i szczęścia. Przekł. A. Sawicka-Chrapkowicz. Gdańskie Wydawnictwo Psychologiczne, Sopot 2020; G.S. Schiraldi: Siła rezyliencji. Jak poradzić sobie ze stresem, trauma i przeciwnościami losu? Przekł. S. Pikiel. Gdańskie Wydawnictwo Psychologiczne, Gdańsk 2019. Por. Model Kompetencji Zawodowych (MKZ). Oprac. A. Bielawiec-Osińska. https://www.biurokarier.umk.pl/model-kompetencji-zawodowych [dostęp: 19.01.2021]; Definicje kompetencji zawodowych. Autorką piktogramów jest M. Kasprzykowska. https://www.biurokarier.umk.pl/definicje-kompetencji-zawodowych [dostęp: 15.01.2021]; TMA Competencies. Competencies and Behavioral Examples. Pobrano z: https:/www.competencylibrary.com/en/Competency/Download?type=pdf [15.01.2021]. 


$$
* * *
$$

Rezyliencja to nie teoria. Rezyliencja to autentyczna wewnętrzna siła, która pozwala mierzyć się ze światem; umożliwia przetrwanie traum. Działa równocześnie jak tarcza osłaniająca przed ,gradem ciosów” i jak kompas, który wskazuje cel.

Każdy z nas ma w określonym stopniu rozwiniętą determinację, pewność siebie, poczucie własnej wartości, odwagę i wiele innych cech [...]. Chociaż zwykle nie odczuwamy ich działania tak intensywnie, to jednak one istnieją i są w gotowości, byśmy mogli sięgnąć do tych zasobów w przypadku krytycznej sytuacji ${ }^{50}$.

Z takimi właśnie granicznymi okolicznościami bez wątpienia mamy dziś do czynienia.

Kompetencje odpornościowe — w koncepcji Stanisława Dylaka należące do tak zwanych kompetencji pożądanych nauczyciela, a przez Marię Czerepaniak-Walczak lokowane wśród kompetencji transgresyjnych, do zmiany — w moim odczuciu są obecnie kompetencjami koniecznymi — umożliwiają wykonywanie profesji nauczyciela na wszystkich szczeblach hierarchii zawodowej. Są niezbędne w procesie przystosowywania się do zmieniających się warunków życiowych, w „oswajaniu” permanentnego dziś stresu (stresu o wręcz granicznym nasileniu), w tworzeniu i utrzymywaniu satysfakcjonujących więzi społecznych, które mogą być źródłem pozytywnych emocji tak bardzo potrzebnych nam wszystkim we współczesnym świecie.

$$
* * *
$$

Rezyliencja jest niezbędna człowiekowi w jego rzeczywistych zmaganiach z nieuchronną transformacją/reorganizacją sposobu myślenia oraz działania; w dzisiejszym zglobalizowanym świecie, niestabilnym, co pokazała pandemia COVID-19, powinna należeć do kompetencji nie tylko nauczyciela akademickiego, lecz także każdego człowieka. Nabywanie wiedzy o zdolnościach adaptacyjnych do zmian jest nie tyle ważne, potrzebne, ile - w moim przeświadczeniu — obligatoryjne. W konkluzji tego tekstu warto podkreślić, iż szczególnie w czasach zarazy wszyscy, niezależnie od wykonywanego zawodu i sprawowanych funkcji czy pozycji społecznej, powinniśmy polegać na swoich siłach wewnętrznych, wzmacniać je i rozwijać.

${ }^{50}$ Rezyliencja - o naszej wewnętrznej odporności. Psychologia. Kolektyw Terapeutyczny. 3.04.2019. https://www.psychologgia-plus.pl/blog/rezyliencja-o-naszej-wewnetrznej-odpornosci/ [dostęp: 24.04.2021]. 


\section{Bibliografia}

Brzeziński J.: Rozważania o uniwersytecie. W: Edukacja wobec zmiany społecznej. Red. J. Brzeziński, L. Witkowski. Wydawnictwo Edytor, Poznań-Torun 1994, s. 23-47.

Co to jest Model Kompetencji Zawodowych (MKZ)? Biuro Karier. Uniwersytet Mikołaja Kopernika w Toruniu. https://www.biurokarier.umk.pl/model-kompetencji-zawodowych1 [dostęp: 12.01.2021].

Czerepaniak-Walczak M.: [hasło:] Kompetencja. W: Jakość kształcenia w szkolnictwie wyższym. Stownik tematyczny. Red. M. Wójcicka. Centrum Badań Polityki Naukowej i Szkolnictwa Wyższego, Uniwersytet Warszawski, Warszawa 2001, s. 69.

Czerepaniak-Walczak M.: Kompetencja: stowo kluczowe czy „wytrych” w edukacji? „Neodidagmata" 1999, nr 24, s. 53-66. Pobrano z: https://repozytorium.amu.edu.pl:8080/bitstream/10593/6514/1/04_Maria_Czerepaniak_Walczak_KOMPETENCJA_S\%C5\%81OWO_ KLUCZOWE_53-66.pdf [6.09.2021].

Czerepaniak-Walczak M.: Refleksja krytyczna i jej miejsce $w$ dyskusji nad reformowaniem oświaty (próba zastosowania). „Rocznik Pedagogiczny” 1997, nr 20, s. 29-47.

Definicje kompetencji zawodowych. Autorką piktogramów jest M. Kasprzykowska. https://www. biurokarier.umk.pl/definicje-kompetencji-zawodowych [dostęp: 15.01.2021]

Duda B., Lisczyk K.: Narzędzia cyfrowe w polonistycznej dydaktyce akademickiej — zastosowania, możliwości, perspektywy. „Forum Lingwistyczne” 2018, nr 5, s. 143-154. Pobrano z: https:// www.journals.us.edu.pl/index.php/FL/article/view/7432 [11.01.2021].

Dylak S.: Wizualizacja w kształceniu nauczycieli. Wydawnictwo Naukowe UAM, Poznań 1995.

Dziedziczak-Foltyn A.: Nauczyciele akademiccy jako prekursorzy i moderatorzy spoleczeństwa wie$d z y$. „Nauka i Szkolnictwo Wyższe” 2006, nr 2 (28), s. 65-78. Pobrano z: https://pressto.amu. edu.pl/index.php/nsw/article/view/4789 [6.09.2021].

Edukacja - jest w niej ukryty skarb. Raport dla UNESCO Międzynarodowej Komisji ds. Edukacji dla XXI wieku. Pod przewodnictwem Jacques'a Delorsa. [Tłum. W. Rabczuk]. Stowarzyszenie Oświatowców Polskich-Wydawnictwa UNESCO, Warszawa 1998.

Encyklopedia filozofii wychowania. Red. S. Jedynak, J. Kojkoł. Oficyna Wydawnicza Branta, Bydgoszcz 2009.

Głowania K.: Modelowa sylwetka wspótczesnego nauczyciela akademickiego. W: Edukacja w zglobalizowanym świecie. Red. V. Tanaś, W. Welskop. Wydawnictwo Naukowe Wyższej Szkoły Biznesu i Nauk o Zdrowiu, Łódź 2016, s. 409-417.

Gołek B.: Kompetencje współczesnego nauczyciela (wybrane obszary). „Rocznik Komisji Nauk Pedagogicznych PAN" 2014, T. 67, s. 87-103.

Hamer H.: Klucz do efektywności nauczania. Poradnik dla nauczycieli. Veda, Warszawa 1994.

Hanson R., Hanson F.: Rezyliencja. Jak uksztattować fundament spokoju, sity i szczęścia. Przekł. A. Sawicka-Chrapkowicz. Gdańskie Wydawnictwo Psychologiczne, Sopot 2020.

Henke M.: Rezylientne przywództwo - czy leci z nami pilot? Małgorzata Henke szkolenia dla biznesu. 2.08.2020. http://malgorzatahenke.pl/2020/08/02/rezylientne-przywodztwo/ [dostęp: 15.09.2020].

Kaniok P.: Kto może zostać nauczycielem akademickim. Wyższa Szkoła Kształcenia Zawodowego. 20.04.2021. https://studia-pedagogiczne.pl/aktualnosci/kto-moze-zostac-nauczycielem-akademickim/ [dostęp: 25.05.2021].

Keil J.: ,, Szukaj własnej drogi”: nauczyciel wychowawca w myśli pedagogicznej Janusza Korczaka. W: Myśl pedeutologiczna i działanie nauczyciela. Red. A.A. Kotusiewicz. T. 2. Trans Humana, Białystok 2000, s. 45-54. 
Klaus P.: Daj się poznać od najlepszej strony. Krótki kurs autopromocji i lansu. [Tłum. M. Czub]. Wydawnictwo Helion, Gliwice 2010.

Kompetencja nauczyciela. MoncoPL. http://monco.frazeo.pl $/ \mathrm{search}$ ? $\mathrm{q}=\mathrm{kompetencje \& o}=\mathrm{on}$ $\& \mathrm{sf}=0 \& \mathrm{o}=\mathrm{on} \& \mathrm{~d}=1 \& \mathrm{dq}=\& \mathrm{~d} \operatorname{sor} \mathrm{t}=\mathrm{id}+\mathrm{asc} \& \mathrm{cs}=1 \& \mathrm{cht}=\mathrm{on} \& \mathrm{f}=\& \mathrm{t}=\& \mathrm{p}=1 \& \mathrm{sd}=2021-01$ 12+02\%3A37\%3A11\&l=20\#results [dostęp: 11.01.2021].

Konarzewski K.: Nauczyciel. W: Sztuka nauczania. Szkoła. Podręcznik dla studentów kierunków nauczycielskich. [T.] 2. Red. K. Konarzewski. [Wyd. 2]. Wydawnictwo Naukowe PWN, Warszawa 1993.

Korczyński S.: Obraz nauczyciela w polskiej myśli pedeutologicznej. WSP, Opole 1992.

Kozak-Łatkowska B.: Koncepcja kompetencji w zarządzaniu zasobami ludzkimi w kontekście uczenia sie przez cate życie. Szkolenia.com. http://www.szkolenia.com/news/806/koncepcjakompetencji-w-zarzadzaniu-zasobami-ludzkimi-w-kontekscie-uczenia-sie-przez-cale-zycie [dostęp: 17.05.2016].

Kuś A.: Ludzie Uniwersytetu w dobie globalizacji. W: V. Tanaś, W. Welskop: Edukacja w zglobalizowanym świecie. Wydawnictwo Naukowe Wyższej Szkoły Biznesu i Nauk o Zdrowiu, Łódź 2016, s. 155-163.

Leary M.: Wywieranie wrażenia na innych. O sztuce autoprezentacji. Tłum. A. Kacmajor, M. Kacmajor. Wyd. 2 w jęz. pol. Gdańskie Wydawnictwo Psychologiczne, Gdańsk 2007.

Markowski A., Pawelec R.: Stownik wyrazów obcych i trudnych. Wydawnictwo Wilga, Warszawa 2001.

Męczkowska A.: [hasło:] Kompetencja. W: Encyklopedia pedagogiczna XXI wieku. Red. T. Pilch. T. 2. Wydawnictwo Akademickie „Żak”, Warszawa 2009, s. 693-695.

Model Kompetencji Zawodowych (MKZ). Oprac. A. Bielawiec-Osińska. https://www.biurokarier. umk.pl/model-kompetencji-zawodowych [dostęp: 19.01.2021].

MoncoPL. http://monco.frazeo.pl/ [dostęp: 14.01.2021].

NKJP. Narodowy Korpus Języka Polskiego. http://nkjp.pl [dostęp: 11.01.2021].

Odporność. Słownik Języka Polskiego PWN. https://sjp.pwn.pl/sjp/odporny;2493503.html [dostęp: 30.12.2019].

Okoń W.: Nowy stownik pedagogiczny. „Żak”, Warszawa 1998.

Prawo o szkolnictwie wyższym i nauce. Dział 2: Szkolnictwo wyższe. Rozdział 5: Pracownicy uczel$n i$. https://sip.lex.pl/akty-prawne/dzu-dziennik-ustaw/prawo-o-szkolnictwie-wyzszym-i-nauce18750400/dz-2-roz-5 [dostęp: 25.02.2021].

Rezyliencja. https://pl.wikipedia.org/wiki/Rezyliencja [dostęp: 30.12.2019].

Rezyliencja - o naszej wewnętrznej odporności. Psychologia. Kolektyw Terapeutyczny. 3.04.2019. https://www.psychologgia-plus.pl/blog/rezyliencja-o-naszej-wewnetrznej-odpornosci/ [dostęp: 24.04.2021].

Sajduk B.: Nowoczesna dydaktyka akademicka. Kto kogo uczy? Wyższa Szkoła Europejska im. ks. Józefa Tischnera, [s.1.] 2014. https://doi.org/10.13140/2.1.4043.2969.

Schiraldi G.S.: Sita rezyliencji. Jak poradzić sobie ze stresem, trauma i przeciwnościami losu? Przekł. S. Pikiel. Gdańskie Wydawnictwo Psychologiczne, Gdańsk 2019.

Słownik języka polskiego. Red. J. Karłowicz, A. Kryński, W. Niedźwiedzki. T. 2. [Nakładem prenumeratorów i kasy im. Mianowskiego], Warszawa 1902, s. 426. https://ebuw.uw.edu.pl/publication/254 [dostęp: 24.04.2021].

Stownik języka polskiego. Red. M. Orgelbrand. [Nakładem autora], Wilno 1861.

Stownik jezzyka polskiego. Red. M. Szymczak. T. 1. Wyd. 7. zm. i popr. Wydawnictwo Naukowe PWN, Warszawa 1992.

Stownik współczesnego języka polskiego. Red. B. Dunaj. T. 1. Wyd. 2. Cykada-Wilga, Warszawa 2000. 
Strawińska A.B.: Autopromocja w edukacji akademickiej. W: Edukacja polonistyczna. Metamorfozy kontekstów i metod. Red. M. Karwatowska, L. Tymiakin. Wydawnictwo Uniwersytetu Marii Curie-Skłodowskiej, Lublin 2017, s. 137-163.

Strawińska A.B.: Historia i definicja terminu personal branding. Zarys problematyki. W: Socjolekt — idiolekt - idiostyl. Historia i wspótczesność. Red. U. Sokólska. Uniwersytet. Wydział Filologiczny-Wydawnictwo Prymat, Białystok 2017, s. 365-387.

Strawińska A.B., Dzięcioł-Pędich A.: „,Rezyliencja” w polskich i angielskich źródtach leksykograficznych [w przygotowaniu].

Strykowski W.: Kompetencje wspótczesnego nauczyciela. „Neodidagmata” 2005, nr 27/28, s. 15-28. Pobrano z: https://repozytorium.amu.edu.pl/bitstream/10593/3096/1/strykowski.pdf [17.05.2016].

TMA Competencies. Competencies and Behavioral Examples. Pobrano z: https://www.competencylibrary.com/en/Competency/Download?type=pdf [15.01.2021].

Tylko 20\% uczniów i studentów lubi się uczyć. Wirtualna Polska. Wiadomości. 26.03.2004. https://wiadomosci.wp.pl/tylko-20-uczniow-i-studentow-lubi-sie-uczyc-6036356228506241a [dostęp: 6.09.2021].

Uniwersalny stownik języka polskiego. Red. S. Dubisz. T. 1. Wydawnictwo Naukowe PWN, Warszawa 2003.

Wędrychowska E.: Rezyliencja - 5 sposobów na to, jak budować swoja ,,warstwę ochronna", by radzić sobie w trudnych doświadczeniach zawodowych. Ewa Wędrychowska blog. http:// ewedrychowska-coaching.pl/blog/rezyliencja-5-sposobow-na-to-jak-budowac-swoja-warstwe -ochronna-by-radzic-sobie-w-trudnych-doswiadczeniach-zawodowych/ [dostęp: 12.01.2021].

Wiśniewska M.: Tożsamość nauczyciela akademickiego. „Forum Dydaktyczne” 2011, nr 7-8, s. 66-76. Pobrano z: https://repozytorium.ukw.edu.pl/bitstream/handle/item/1781/Malgorzata-Wisniewska-Tozsamosc-nauczyciela-akademickiego.pdf? sequence=1\&isAllowed=y [6.09.2021].

Wołoszyn S.: [hasło:] Nauczyciel. W: Encyklopedia pedagogiczna. Red. W. Pomykało. Fundacja „Innowacja”, Warszawa 1993, s. 439-445.

Woodruffe Ch.: Ośrodki oceny i rozwoju. Narzędzia analizy i doskonalenia kompetencji pracowników. Oficyna Ekonomiczna, Kraków 2003.

Wróblewski A.K.: Wizja uniwersytetu przyszłości. „Nauka” 2010, nr 2, s. 11-17.

Znaniecki F.: Społeczne role uczonych. Wybór, wstęp, przekł. tekstów ang. i red. nauk. J. Szacki. Państwowe Wydawnictwo Naukowe, Warszawa 1984. 